\title{
CONTRIBUTIONS TO THE FLORA OF CEYLON (SRI LANKA)
}

\author{
L.H. CRAMER \\ Department of Botany, Eastern University, Sri Lanka.
}

(Date of receipt : 04 May 1990)

(Date of acceptance : 22 October 1990)

\begin{abstract}
An investigation into the Flora of the Polonnaruwa District (southern part*) has revealed the existence of additional taxa in the Flora of Ceylon (Sri Lanka). These include a new species of $R$ binacanthus Nees, two new species records for the country, and a distributional record for the dry low country (inclusive of Polonnaruwa Drstrict) in Cantbium puberulum Thwaites ex Hook. f., a rare endemic species of the Rubiaceae, hitherto known only from the Central Province. Ecology notes provide additianal data to specific descriptions of specimens encountered in the field. Respective illustrations of the species described are provided.
\end{abstract}

\section{Introduction}

In the course of a floristic survey of the flora of the Polonnaruwa District (southern part*) the occurrence of some angiosperm species, unusual for Ceylon, was observed for the first time. Subsequent investigations proved these to include a new species of Rhinacanthus (Acanthaceae), two new species records for Ceylon, and a distributional record of an endemic species (Rubiaceae) for the dry low country (inclusive of the district) hitherto not recognized.

\section{Materials and Methods}

The data for the determination of these taxa were based on field collections and observations in the study area, laboratory studies of fresh representative specimens, and of herbarium material in the EUSL***, the National Herbaria of Kew (England), Peradeniya and Singapore, and the Rapinat Herbarium, Tiruchirapalli (India).

\section{Taxa}

\subsection{New Species of Rhinacanthus Nees}

The genus Rhinacanthus Nees of the Acanthaceae, a pantropic family, has been represented so far in South and South-East Asia by only one species, $R$. nasutus. (L.) Kurz., occurring in the lowlands of Ceylon, including the

* It lies between $80^{\circ} 40^{\prime}$ and $81^{\circ} 20^{\prime}$ east longitude and $7^{\circ} 41^{\circ}$ and $80^{\circ} 60^{\prime}$ north latitude, and covers an expanse? of $1,567 \mathrm{~km}^{2}$ of land.

*** Unofficial abbreviation for the Herbarium, Eastern University, Sri Lanka. 
Polonnaruwa District. The new species described below forms yet another representative of the genus for this asiatic region.

\section{R. polonnaruwensis** Cramer, sp. nov.}

Haec species $R$. nasuto (L.) Kurz affinis sed, ab ea caule in parte superiore pendente, foliis linearibus marginibus distincte undulatis atque radicibus vermicularibus differt.

Herba perennis; radices vermiculares; caulis usque $110 \mathrm{~cm}$ altus, parte tamen superiore pendens. Folia linearia, $4.2-10 \times 0.3-0.6 \mathrm{~cm}$ basi attenuata, apice acuta, marginibus distincte undulatis. Thyrses terminales, laxae, usque ad $15 \mathrm{~cm}$ longae; peduncula dense glanduloso-pilosula, pilis ;interspersa hirsutis; bracteae lanceolatae, $2-3 \mathrm{~mm}$ longae. Flores fasciculati; calyx profunde 5-partitus; lobi lineari-lanceolati, $2.5-3.0 \times 0.5-1.2 \mathrm{~mm}$, acuminati, extra glanduloso-pilosuli; corollae tubus usque $2.7 \mathrm{~cm}$ longus, supra leviter dilatatus, labium superior ovali-oblongum, $6.0 \times 3.0 \mathrm{~mm}$, apice 2-fidum; labium inferior usque $1.2 \mathrm{~cm}$ latum. Capsula clavata, 1.5$1.7 \times 0.3 \mathrm{~cm}$, longe stipitata; stirps tenuis; retinacula lineari-lanceolata, sursum incurvata; semina 4, helicoidio-reniformia, muricata.

Perennial herb; roots vermicular; stem to $110 \mathrm{~cm}$ high, sagging in upper part. Leaves linear, to $4.2-10 \times 0.3-0.6 \mathrm{~cm}$, attenuate at base, acute at apex, distinctly uridulate at margins. Thyrses terminal, lax, to $15 \mathrm{~cm}$ long; peduncles densely glandular-pilosulose, interspersed with eglandular hairs; bracts linear-lanceolate, 2-3 mm long. Flowers clustered; calyx deeply 5-partite; lobes linear-lanceolate, $2.5-3 \times 0.5-1.2 \mathrm{~mm}$, acuminate, glandular-pilose without; corolla tube to $2.7 \mathrm{~cm}$ long, faintly dilated above; upper lip oval-oblong, $6 \times 3 \mathrm{~mm}$, 2-fid at apex; lower lip to $1.2 \mathrm{~cm}$ across. Capsule clavate, $0.5-1.7 \times 0.3-0.4 \mathrm{~cm}$, with a long stalk. retinacula linear-lanceolate, curved upwards; seeds 4 , helicoid-reniform, $1 \mathrm{~mm}$ broad, muricate.

Flowering : August - September; flowers white.

Ecology: The plant occurs in patches under shade in sandy-loam soil in close vacinity to a stream or river.

Illustration. Figure 1.

Distribution. Sri Lanka: North Central Province; Polonnaruwa District; Bakamuna, under shade of trees in secondary, semi-evergreen forest, Cramer 5923 (holotype EUSL***; isotypes $\mathrm{K}, \mathrm{PDA}$ ); Mahawewa, in secondary, semi-evergreen forest,Cramer 6053 (EUSL, PDA); Wasgomuwa Oya, in secondary, semi-evergreen forest, Vivekananda \& Tambipillai 149 (EUSL***, PDA). 


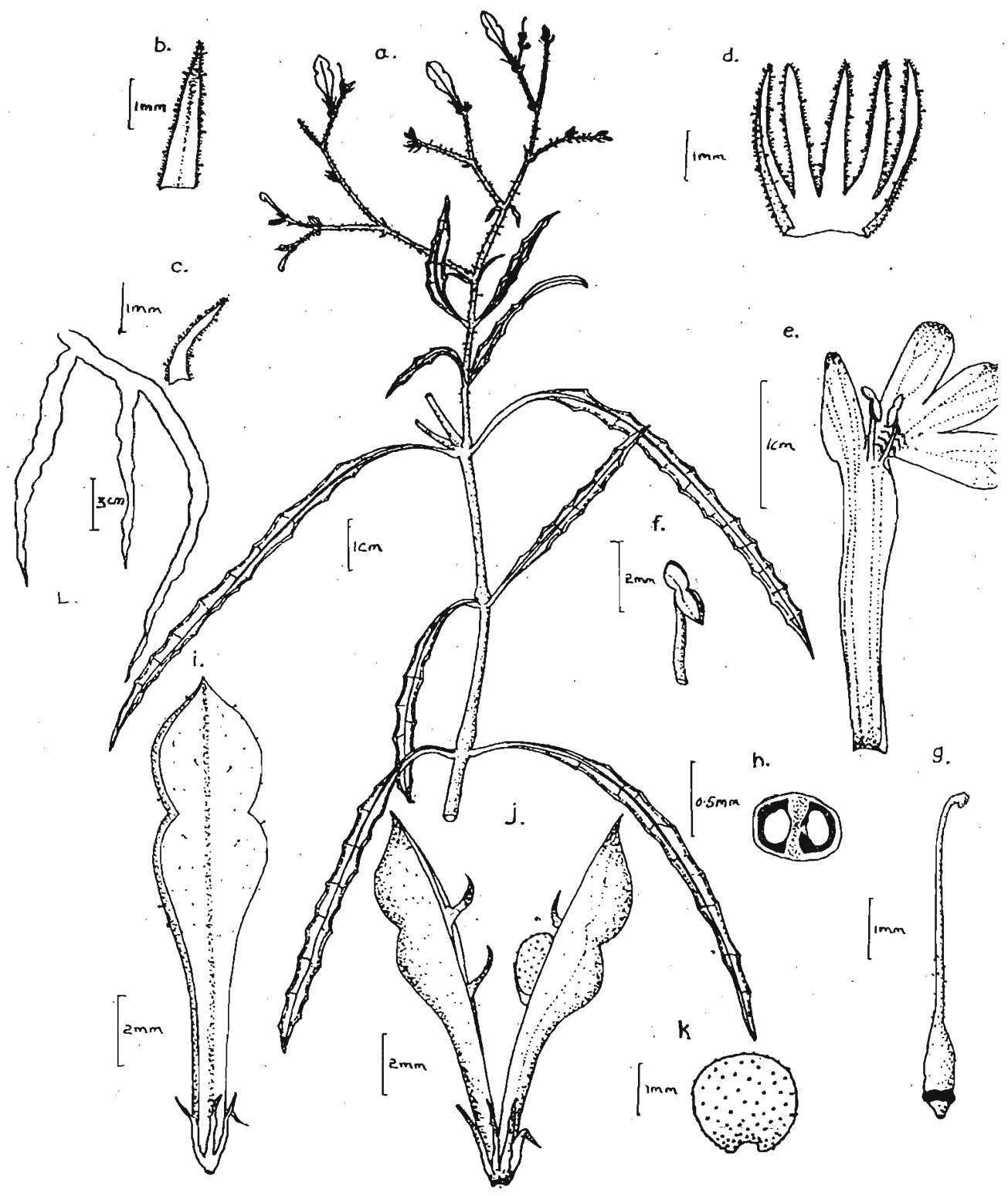

Figure 1: Rhinacantbus polonnaruwensis Cramer.

a. flowering branch; b. bract; c. bracteole; d. calyx split open (inner view); e. dissected corolla; f. anther; g. gynoecium; h. t.s. ovary; i. capsule (surface view); j. dehisced capsule; $k$. seed; 1 , roots. 
Note. On many visits to the locality of the plant the inflorescences were observed only in fruit. Flowers occur only during a limited period of the year as stated above.

The weakness of the upper part of the stem brings about its sagging nature. This character, that of the linear leaves with undulate margins and the fruiting inflorescences during most of the year are very distinctive in the field.

The novelty of this species has been confirmed by the author's research in the herbaria mentioned under Meterials and Methods.

\subsection{New records}

Note. Unless otherwise indicated, the collection numbers refer to those of Cramer \& Jayaratnam.

\subsubsection{Rubiaceae}

\subsubsection{Borreria G. F. W. Meyer, nom: cons.}

Note. On examination of the East African species of this complex Verdcourt ${ }^{4}$ recognized, in the detachment of the septum from one or both capsular valves (or neither), respectively in Spermacoce L. and in Borreria the only differential character between the two genera. Considering this as of hardly any taxonomic weight he accordingly merged the latter in the former (based on priority).

Notwithstanding Verdcourt's ${ }^{4}$ position I prefer to follow the practice of retaining the nomina generica conservanda of the International Code of Botanical Nomenclature ${ }^{5}$ in regard to the case of Borreria. I would still accept, therefore, Hepper's ${ }^{1}$ earlier adoption of this name (for the African complex) and Santapau's ${ }^{2}$ further retention of the name (for the Indian complex) according to the practice of the Code.

3.2.3 Borreria distans (H.B.K.) Cham. \& Schlecht., Linnea 3(4): 340. 1828; A. DC., Prodr. 4 (2): 542. 1830; Backer \& Bakhuizen v.d. Brink, Fl. Java $2: 353.1965$.

Spermacoce distans H. B. K., Nov. Gen. \& Sp. 3 : 344.1819. 
Perennial herb; stem to ca. $30 \mathrm{~cm}$ high, much branched, woody at base, quadrangular, scaberulous on angles above. Lower leaves opposite, upper ones whorled, all sessile, linear-oblong to linear-lanceolate, $2.2-4.5 \times 0.5-$ $0.8 \mathrm{~cm}$.; stipules adnate in pairs into a shallw cup, pectinate, Cymes terminal, clustered in semi-lunar heads; bracts linear, to $3 \mathrm{~mm}$ long. Corolla tube to $1.25 \mathrm{~mm}$ long; lobes triangular-ovate, to $1.5 \mathrm{~mm}$ long; stamens exserted; stigmatic branches globose. Capsule ovoid-oblong, sub-compressed; septum split longitudinally, undetached from values; seeds oblong, 2-3 x $1 \mathrm{~mm}$, plano-convex, ventrally grooved, reticulately nerved.

Flowering. January - March; flowers white, inconspicuous.

Ecology. A weed with a strong tap root in sandy ground, often along grassy roadsides; fairly common.

Illustration. Figure 2

Distribution. Habarana, 6067 (EUSL***, PDA).

Also in Tropical America and Indonesia.

Note. The broad tops of heads subtended by the whorl of leaves are very distinctive.

\subsubsection{Acanthaceae}

\subsubsection{Pseuderanthemum Radlkf.}

3.2.3.2 P. angustifolium Rideley, J. Fed. Mal. St. Mus. 10: 107. 1920.

Annual, to ca. $120 \mathrm{~cm}$ high, sparsely branched. Leaves linear to linearelliptic, $5-13.5 \times 0.2-1.2 \mathrm{~cm}$, cuneate at base, undulate at margins; petioles to $5 \mathrm{~mm}$ long. Spikes terminal, to $14 \mathrm{~cm}$ long; bracts lanceolate, 2-3 x $0.5 \mathrm{~mm}$. Corolla tube $1.5-1.6 \mathrm{~cm}$ long, faintly broadened at throat; limb to $2.2 \mathrm{~cm}$ across; anther thecae puberulous at apex; staminodes linear-lanceolate, curved upwards. Capsule clavate, to $1.8 \times 0.4 \mathrm{~cm}$; retincacula linearlanceolate, curved upwards; seeds suborbicular, $4 \times 3 \mathrm{~mm}$, alveolate. 


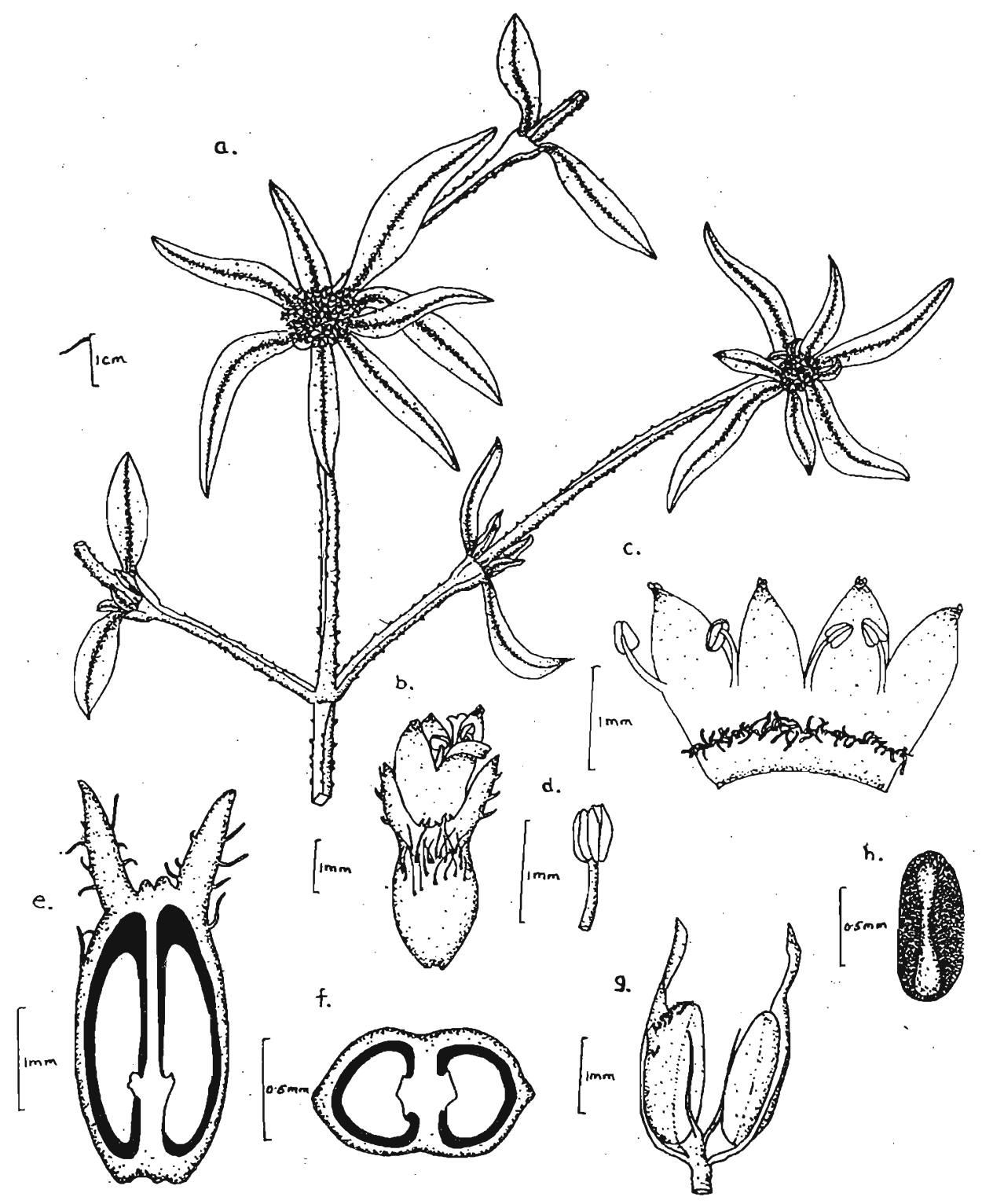

Figure 2 - Borreria distans (H. B. K.) A. DC.

a. flowering branch; b. flower; c. dissected corolla $a_{i}$ d. stamen; e. l.s.ovary; f. t.s. ovary; g. dehisced capsule; $\cdot$ h. seed. 
Flowering. June--August; flowers white, dotted pale purple on upper lip, soon deciduous.

Ecology. Under shade of trees close to a stream or a river in sandy-loam soil of secondary, semi-evergreen forest; occasional.

Illustration. Figure 3.

Distribution. Mahawewa: Mlukgama, 5888 (EUSL***, PDA).

Also in Malaysia.

Note. This species is allied to P. latifolium (Vahl) Hansen (syn. P. malabaricum C. B. Clarke) from which it clearly differs in the linear shape of leaves and the entire straightness of the corolla tube.

\subsection{New distribution record}

\subsection{Rubiaceae}

3.3.2.1 Canthium puberulum Thwaites ex Hook. f., F1. Brit. Ind. 3: 134. 1882; Trimen, Handb. Fl. Ceyl. 3:206.1895.

Shrub to ca. $3 \mathrm{~m}$, diffusely branched; spines supra-axillary, slender. Leaves elliptic-ovate to obovate, $1.4-3 \times 1.1-2 \mathrm{~cm}$. Flowers axillary, solitary or binary. Drupes ovoid or oboviod.

Flowering. November - December; flowers white, turning pale green with age.

Ecology. Under shade of trees in loamy soil of degraded, semi-evergreen forest close to streams; rare. Endemic.

Illustration. Figure 4.

Distribution. Habarana (Galwanguwa), 6005 (EUSL***, PDA).

Note. Trimen ${ }^{3}$ cites 'Central Province' (C. P. 3995) as the only distribution locality of this species in Ceylon. Except for the C.P. specimen there is no other representative specimen of it in the National Herbarium, Peradeniya. Our subsequent location of this species at Habarana must be considered, therefore, a new distributional record for the species locally and climatologically, occurring as it does in the 'dry zone' of the low country:

\section{Discussion}

The flora of Ceylon (Sri Lanka) is still not completely documented, certain areas in the country being not yet fully investigated floristically. The present contributionsto this flora, from a monitoring of the plants of the Polonnaruwa District, one such unexplored area, fill: some lacunae still left in the complete documentation of this flora. 
174

L.H. Crater

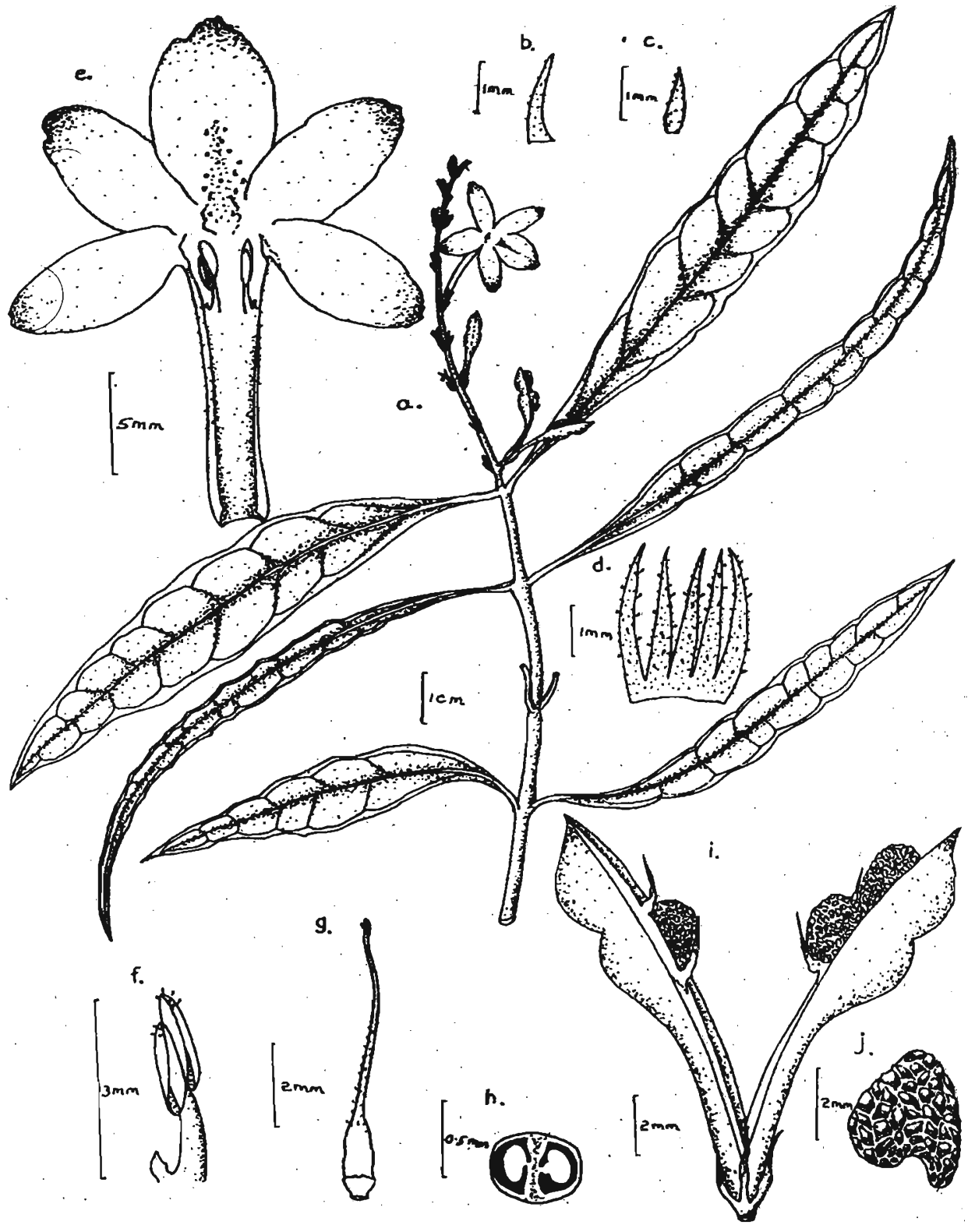

Figure 3 : Pseuderanthemum angustifolium Ridley

a. flowering branch; b. bract; c. bracetole; d. calyx split open; e. dissected corolla; f.stamem \& staminode; g.xgynoecium; h. ts. ovary; i. dehisced capsule; j. seed. 

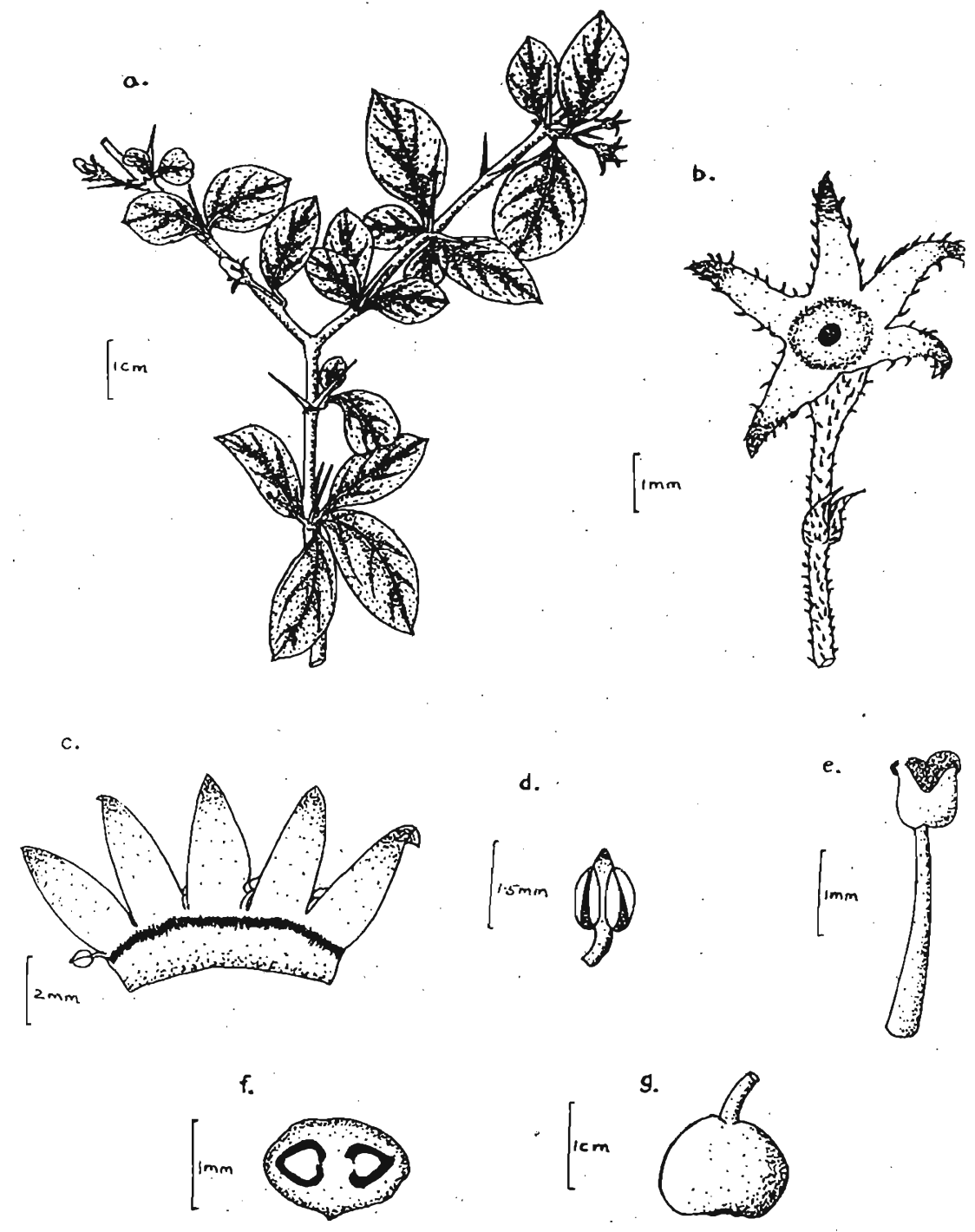

Figure 4 : Cantbium puberulum Thw. ex Hook. f.

a. flowering branch; b. flower; c; corolla split open; d. stamen; e. style and stigma. f. t.s. ovary; g. fruit. 
The new species described adds to the widespread distribution of the Acanthaceae in the Polonnaruwa District where representatives of 21 of its genera, out of the 31 presently reported for Ceylon $\left(\right.$ Trimen $^{3}$ ), occur.

The new species records form an additional confirmation of the affinity of our flora with that of the Malaysian region.

\section{Acknowledgements}

The investigation into the flora of the southern part of the Polonnaruwa District was done on a grant from the Natural Resources, Energy and Scierice Authority, Sri Lanka. Grateful thanks are expressed to the Directors, Royal Botanic Gardens, Kew, England, Botanic Gardens, Singapore, the Rapinat Herbarium, Tiruchirapalli, India, and to Dr. A.H.M. Jayasuriya, Curator, National Herbarium, Peradeniya, for generous facilities to work in these respective herbaria; also to Dr. R.K. Brummitt of the Herbarium, Kew, for assistance in the characterization of the new species.

Grateful commendations are due to Miss S.J. Jayaratham, Research Assistant, for the preparation of the line diagrams.

\section{References}

1. HEPPER, FN. (1960) Notes on Tropical African Rubiaceae. 1. (Borreria, nom, cons.) Kew Bull. $14(2): 255-260$.

2. SANTAPAU, H. (1967) The Flora of Khandala on the Western Ghats of India. (ed. 3.). Delhi : Government of India Press.

3. TRIMEN, H. (1895) Handbook to the Flora of Ceylon. $3: 234-235$. London: Dulau \& Co.

4. VERDCOURT, B. (1976) In Turill, W.B. \& al. (eds.). Fl. Trop. East Afr. Vol. 1 (Rubiaceae). London.; Grown Agents.

5. VOSS, E.G. \& al. (eds., 1983) The International Code of Botanical Nomenclature $\Varangle$ Appendix III A.p. 293. Utrecht : W. Junk. 


\section{Journal}

of the

National

Science

\section{Council of \\ Sri Lanka}

\section{Instructions to Contributors}

Aims and Scope

The purpose of this Journal is to provide a medium for the quick dissemination of the results of research in all fields of Science and rechnology. Published material will range from original contributions is review articles describing the state of the art in specific areas, together with short communications

Editorial Board

Prof. B.A. Abeywickrama

Prof. V. Basnayake

Prof. C.B. Dissanayake

Prof. S.T. Fernando

Prof. V.K. Samaranayake
Prof. T.E.J. de Fonseka

Dr. R. Mahindapala

Dr. E.R. Jansz

Manuscripts and all correspondence relating to them should be sent to The Editor Editorial Board, Journal of the National Science Council of Sri Lanka, 47/5 Maitland Place, Colombo 7, Sri Lanka. 
JOURNAL OF THE

\section{NATIONAL SCIENCE COUNCIL \\ OF SRI LANKA}

\section{INSTRUCTIONS TO CONTRIBUTORS}

Manuscripts and all correspondence relating to them should bo sent to :

The Secretary, Editorial Board, Journal of the National Science Council of Sri Lanka,

47/5 Maitland Place, Colombo 7, SRI LANKA.

\section{EDITORIAL POLICIES}

Submission of Papers : Papers are accepted for editorial consideration with the understanding that they have not been published, submitted or accepted for publication elsewhere. Papers accepted for publication may not be published elsewhere in the same form, either in the language of the paper or any other language, without the consent of the Editorial Board.

Research papers, Papers read at Symposia and Reviews may be submitted to the Editorial Board. Research papers should describe original investigations or technological achievements. Reviews should be critical evaluations of existing knowledge in a specialised field. The Journal also accepts Short Communications. They should be submitted if the results are of sufficient importance to merit publication in advance of a full paper.

Languages of Publication : Sinhala, Tamil and English.

Refereeing and Editing : All material submitted is examined by two or more referees prior to publication. Papers are edited to increase clarity and ease of communication. In preparation for the press, particular attention is paid to grammar and the conventions of the Journal with regard to symbols, illustrations, tables, references and nomenclature.

Manuscripts submitted for editorial consideration can be processed expeditiously if they conform from the outset to the style of the Journal. Authors are therefore advised to follow closely the form described in these instructions.

\section{PRESENTATION OF MANUSCRIPTS}

No maximum length of contributions is prescribed but papers should be written clearly and concisely. All unnecessary textual matter, figures and tables must be eliminated. In general, the impersonal form should be used.

Supplementary material of a detailed nature, which is not essential in the printed paper, but may be useful to other workers, may be deposited with the Secretary. Such material will be made available to other scientists on request and a note to this effect should be included in the paper.

The paper should be reasonably subdivided into sections, and if necessary, sub-sections. The following pattern is suggested for Research Papers : (a) Introduction (b) Experimental (c) Results (d) Discussion (e) Conclusions (f) Acknowledgements (g) References. In many cases, two of sections (b), (c) and (d) can be combined. When a separate Discussion is used, it should not recapitulate the results but discuss their significance and relation to the object of the work and to the work of other people. Conclusions should not merely repeat preceding sections.

Special care must be taken in citing references correctly. Responsibility for the accuracy of these rests entirely with the authors. It is the authors' responsibility to obtain written permission to reproduce material which has appeared in another publication.

\section{FORM OF MANUSCRIPTS}

Manuscripts should be submitted in triplicate - including the original typewritten copy - typed throughout in double spacing on one side of the paper only. Adequate margins should be left $(4 \mathrm{~cm})$ with liberal spacing at the top and bottom of each page. The typescript should be free of corrections. 
Headings of major sections should be centred and sub-section headings should be placed on the left of the page. The complete set of headings and sub-headings in an article should be numbered following the style adopted in this Journal and the set should reflect the logical development of ideas.

Paging : Each page of the manuscript should be numbered and the name of the first author and page number indicated in the upper right-hand corner of the page. The first page should contain the article title, the name(s) of the author(s) and name and address of the establishment where the work was carried out. In the case of co-authors, respective addresses should be clearly indicated. Female authors should include one of their given names. The title should be concise but informative. The first word of the title should preferably be one useful in indexing and information retrieval. Where a series of related papers is submitted, each individual paper should have the same general heading, followed by a series number and title of the part. Any footnote to the title should be given at the bottom of this page.

The second page should contain an abstract (of not more than 250 words) which should be a summary of the entire paper, not of the conclusions alone and intelligible without reference to the paper itself. The text should begin on page three and each subsequent major section-references, figure legends and table legends should begin on a new sheet.

The last page should contain (a) a note as to the number of manuscript pages, figures and tables, (b) proposed running title of less than 42 characters (letters and spaces) and (c) the name and mailing address of the person to whom the proofs should be sent.

Illustrations : All illustrations are considered as figures and each graph, drawing or photograph should be numbered in sequence with Arabic numerals. Authors must submit the original and two duplicates of each figure. Figures should be planned to fit the proportions of the printed page $(12 \times 17 \mathrm{~cm})$.

Figures must be drawn. In Indian ink on plain white paper or board or tracing paper, not larger than $20 \times 30 \mathrm{~cm}$. Drawings should be lettered with a lettering set; lettering should be kept large enough to be legible after a reduction of 50 to $60 \%$. If this is not possible, all letters and numerals must be inserted clearly and lightly in blue pencil and not in ink.

Each figure should carry a legend so written that the general meaning of each illustration can be understood without reference to the text. The amount of lettering on a drawing should be reduced as far as possible by trausferring it to the legend. Figure legends should be typed on a separate sheet and placed at the end of the manuscript.

Graphs should be plotted on white or blue-lined graph paper or tracing cloth; grid lines that are to be shown in the engraving should be inked in black. The caption of each axis should be lettered parallel to its axis. Each figure should be identified in the margin with author's name and figure number. The preferred position of all illustrations should be ndicated in pencil in the manuscript.

Photographs : Half-tone illustrations should be included only when essential. Good glossy prints with sharp contrasts between black and white areas should accompany the manuscripts; they should not be attached to manuscript pages. The size should be such that when the print is reduced to the normal size for reproduction (12 x $17 \mathrm{~cm}$ maximum), the detail is still clear. Magnification should be indicated with a scale line on the photograph. The author's name and figure number should be given on the back of each photograph.

Tables should not repeat data which are available elsewhere in the paper. Each table should be typed on a ser zrate sheet with due regard for the proportions of the printed page. They should be numbered consecutively with Arabic numerals. Tabulated matter should be clearly set out and the number of columns in each table should be kept as low as possible. Tables should have legends which make their general meaning clear without reference to the text and all table columns should have explanatory headings. Units of measure should be indicated in parentheses in the heading of each column. Vertical lines shouid not be used and horizontal rules used only in the heading and at the bottom. A one-column table may be up to 42 characters (letters and spaces) wide. A two-column table may be 90 characters wide. Footnotes to the tables are to be 
placed directly below the table and should be indicated by superscript lower-case italic letters $(a, b, c$, etc.). Each table should carry on the back of the sheet the author's name and figure number. The preferred position of tables should be indicated in pencil in the manuscript.

References to the literature must be indicated in the text by a small superior number referring to the list of references which must be inserted on a separate sheet at the end of the paper. The list should be arranged in alphabetical order by author and numbered in Arabic numerals. All authors' initials must be given after surnames. The year of publication should follow in parentheses. When journal articles are listed, the journal name should be abbreviated in accordance with the World List of Scientific Periodicals 1900-1960, 1972, 4th edn, London : Butterworths Scientific Publications. If the journal is not in this list, the name should be given in full. The abbreviated journal title should be underlined to indicate italic type and followed by the volume number underlined with a wavy line to indicate bold type, the issue number in parentheses and then the inclusive pages. When books are listed, the order should be : author(s), year, book title, volume number, edition, pagination/inclusive pages, place of publication and publisher. When sections of a book are listed the order should be : author (s) of section, year, the word In followed by author of book, book title, volume number, edition, inclusive pages, place of publication and publisher. The series title of a book should be given in parentheses after the publisher.

Examples :

Journal - Angmor, J.E., Dicks, D. M., Evans, W. C. \& Santra, D.K. (1972) Planta Med. 21(4): 46-420.

Book - SchoKmaN, D. (1966) Vegetable growing : local and exotic varieties, 29p. Colombo: Agriculture Department.

Section of

Book - ZitNaK, A. (1973) In Chronic cassava toxicity : proceedings of an interdisciplinary workshop, London, England, 29-30 January 1973, pp. 89-95. Ottawa: International Development Research Centre. (IDRC-00e).

Footmotes which are indispensable should be indicated in the text by small superior figures and listed on a separate page in the manuscript
Abbreviations and Symbols recommended in the various parts of British Standard 1991 : Letter symbols, signs and abbreviations should be used. Authors are encouraged to use the S.I. System of units (see description in British Standard PD 5686 : The use of S. I. Units).

Authors whose papers contain mathematical expressions should submit a list of the symbol used carefully and clearly indicated for the guidance of the printer. This list will not appear in print.

Formulae and Equations : Equations should be typewritten and quadruple spaced. They should be started on the left margin and the number placed in parentheses to the right of the equation.

Nomenclature : Scientific names of plants and animals will be printed in italics, and should be underlined in the manuscript. In the first citation, genus, species and authority must be given. e. g. Tylenchorhynchus clayton! Steiner. In later citations, the generic name may be abbreviated to its initial letter. e.g. T. claytoni.

Special instructions in the fields of Physical, Chemical and Medical Sciences are available on application to the Secretary.

Short Communications : The Journal may include a limited number of short communications. Authors should submit short communications only when they believe that rapid publication of their results is of the utmost importance. A short communication must not exceed 1,200 words, i.e. 4 pages of copy inclusive of illustrations and tables. Short communications should be complete in their own right and suitable for citation. The title should indicate the content clearly as these papers do not carry abstracts.

Proofs : Corrected galley proofs must be returned to the Secretary without delay as directed. Failure to do so will result in delay in publication. Correction of proofs by authors must be restricted to printer's and similar errors. They should be marked in pencil. Any modification of the original text is to be avoided. Responsibility for correcting proofs rests entirely on the authors though editorial assistance will be provided.

Reprints : 50 reprints will be supplied free of charge for each article. Additional reprints can be ordered on the reprint order form which will accompany the proofs. 